\section{New year, new BioTechniques}

$\mathrm{H}$

appy New Year to all of our readers!

Since BioTechniques joined Future Science Group around a year ago we've been busy, and I'm delighted to update you on our latest changes.

You can now find our lovely new website at www.biotechniques.com, where you can find all the latest news and educational webinars, as well as interviews and opinions from key leaders in the field, in the form of written pieces, videos and podcasts.

We've also been taking steps towards improving reproducibility, which is a matter close to our hearts. We are delighted to have partnered with Profeza, in a collaboration that allows our authors to turn relevant protocols into a clear and concise 'Reuse Recipe'. Those using the recipe can report reuse, and contact the authors for any troubleshooting or discussions if required. Authors are then able to update the recipe document if they discover it would benefit from tweaks or further clarity. You can view our first such document in Thompson \& Hrabak's "Capture and storage of plant genomic DNA on a readily available cellulose matrix" (BioTechniques 65[5], 285-287 [2018]) - the recipe document also has its own DOI.

Finally, you may have noticed that this print edition of BioTechniques has a new look - we hope you enjoy the new format, which has been designed to improve your reading experience.

That's it from me, but make sure you turn to page 12 to hear from Managing Editor Joseph Martin and Digital Editor Abigail Sawyer, who have taken a

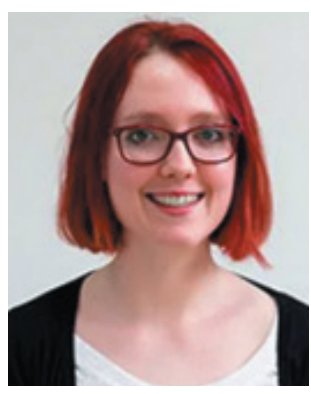

look back over their content highlights of 2018.

\section{Francesca Lake}

Head of Open Access Publishing, Future Science Group, Unitec House, 2 Albert Place, London, UK. f.lake@future-science.com

BioTechniques is a peer-reviewed journal dedicated to the publication of original laboratory methods, related technical tools, and methods-oriented review articles that are of broad interest to scientists engaged in basic applied life science research. Complete Instructions for Authors are available at: https://mc04.manuscriptcentral. com/fs-btn, BioTechniques' website for online manuscript submission. All manuscripts should be submitted at this site.

\section{BioTechniques Staff}

Editorial, Production \& Circulation

Chairman: James Drake

Managing Director. Phil Garner

Publisher. Cheryl Wall

Head of Open Access: Francesca Lake

Managing Editor. Joseph Martin

Digital Editor: Abigail Sawyer

Head of Production: Kathryn Berry

Sales \& Business Offices

Advertising: Cheryl Wall • cwall@biotechniques.com

Subscriptions: Dominik March • d.march@future-science.com

Reprints: Sam Cavana • s.cavana@future-science.com

List Rental: Leela Ripton • I.ripton@future-science.com

Permissions: Adriana Gonzalez • a.gonzalez@future-science.com

\section{Editorial Board}

Bill Brizzard, Indiana University Research and

\section{Technology Corp.}

Bruce Budowle, UNT Health Science Center

Piotr Chomczynski, Molecular Research Center

Rita R. Colwell, University of Maryland-College Park and Johns

Hopkins University

Joshua J. Coon, University of Wisconsin-Madison

David Cronk, Charles River Laboratories

Manel Esteller, Spanish National Cancer Centre (CNIO)

Jeffrey Felton, Western University of Health Sciences

Erica A. Golemis, Fox Chase Cancer Center

Peter M. Gresshoff, The University of Queensland

Yoshihide Hayashizaki, RIKEN

Jörg Hoheisel, German Cancer Research Center

Pui-Yan Kwok, University of California, San Francisco

Rachael L. Neve, Massachusetts Institute of Technology

Peter J. Oefner, University of Regensburg

Stephen W. Paddock, University of Wisconsin-Madison

Scott D. Patterson, Gilead Sciences, Inc.

Leonard F. Peruski, Jr., Centers for Disease Control

George Poste, Arizona State University

John Quackenbush, Harvard School of Public Health

Joshua Rappoport, Northwestern University School of Medicine

John Rossi, City of Hope

Michel Goedert, MRC

Herbert P. Schweizer, Colorado State University

Barton Slatko, New England Biolabs

Steve S. Sommer, MEDomics, LLC

Igor Stagljar, University of Toronto

Mathias Uhlén, The Royal Institute of Technology

Timothy Veenstra, SAIC-Frederick, Inc.

Kent E. Vrana, Penn State College of Medicine

Michael Weiner, AxioMx 